\title{
The effect of different methods of improving the botanical composition of permanent pasture
}

\author{
A. ANDRIES and A. VAN SLIJCKEN \\ Nationaal Centrum voor Grasland- en Groenvoederonderzoek - 1e Sektie. Rijksstation \\ voor Plantenveredeling, Lemberge. \\ Centrum voor Landbouwkundig Onderzoek, Gent, België.
}

\section{Summary}

The results discussed prove that the botanical composition and productivity of inferior permanent grassland can be considerably improved by management (grazing technique and other cultural practices), assisted by adequate manuring. However, this method is only considered to be effective after a relatively long period.

On the other hand, the situation can be changed immediately by ploughing or surface cultivation followed by reseeding with improved grass and clover strains.

\section{Introduction}

It is well known that the grazing animal, good management and a high standard of fertility have a good effect on the botanical composition of the sward. This is owing to the fact that grassland is an unstable vegetation and changes in management, grazing intensity, manuring, etc. affect the balance of the species that make up the sward.

The long-term improvement method (fertilization, better grazing technique and other cultural practices) was therefore compared with the short-term one (ploughing and reseeding).

\section{Experimental procedure}

A number of treatments were tested from 1954 onward on an extensively grazed pasture situated on loam soil with a normal moisture status, but with inadequate fertilization. The following four treatments are discussed in the present paper: -

a. control plot, no fertilizers except for $60 \mathrm{~kg} \mathrm{~N} /$ year/ha in two applications;

b. treatment with mineral fertilizers, $120 \mathrm{~kg} \mathrm{P} \mathrm{O}_{5}, 120 \mathrm{~kg} \mathrm{~K} 2 \mathrm{O}$ and $150 \mathrm{~kg} \mathrm{~N}$ (in 5 applications) /year/ha. In 1959 the $\mathrm{P}$ - and $\mathrm{K}$-fertilization was reduced to $60 \mathrm{~kg}$ $\mathrm{P}_{2} \mathrm{O}_{5}$ and $60 \mathrm{~kg} \mathrm{~K} \mathrm{O}_{2}$;

c. treatment with mineral fertilizers as in treatment b, supplemented by the application of 30 ton dung/ha every other year. In the years when manure was applied, $\mathrm{K}_{2} \mathrm{O}$ was omitted, $\mathrm{P}_{2} \mathrm{O}_{5}$ reduced to $30 \mathrm{~kg} / \mathrm{ha}$ and $\mathrm{N}$ not applied at the first grazing;

d. ploughing and reseeding, completed with mineral fertilizers, as in treatment $b$.

Received for publication 16th December, 1964. 
The seed mixture used consisted of (in $\mathrm{kg} / \mathrm{ha}$ ): Lolium perenne, Pasture type R.v.P. (4) - Festuca pratensis, Intermediate R.v.P. (15) - Phleum pratense, Pasture type R.v.P. (10) - Poa pratensis R.v.P. (3) - Poa trivvialis, Commercial seed (3) — Trifolium repens, New Zealand (5).

The four treatments with two replicates, each with a surface of $1000 \mathrm{~m}^{2}$, were rotationally grazed by heifers five times a year. On the control plot all such cultural pratices, as mowing and spreading of droppings after grazing were omitted.

Dry-matter yields were measured before each grazing period and estimates made of the botanical composition by dry weight analysis at each grazing in order to check the seasonal variation in species. From year to year botanical changes were studied by the frequency method of DE VRIES (1937). 100 samples were taken from each plot.

\section{Botanical data}

Only the major species in the sward are mentioned in this report. FIG. 1 shows that on poor grassland the botanical composition can be improved merely by rotational grazing; when assisted by adequate mineral dressing this improvement is even more effective. Addition of organic fertilizers gives no increase in good grasses.

After 10 years the sward composition on the reseeded treatment was almost completely made up of good grasses, especially Lolium perenne $(72 \%)$ and white clover. The effect of management on the botanical composition is also reflected in the grade of quality (FIG. 1).

It is well known that botanical data obtained by the dry-weight method give excellent results on the actual value of the sward at the moment of sampling, but in order to study the changes in frequency of occurrence of the different species during the experimental period (10 years) samples were taken every winter, according to the frequency method of DE VRIES. The frequency percentages of the major species (the percentage of the total number of 25 sq.cm-samples in which a certain species is noted) are shown in FIG. 2 .

Lolium perenne (FIG. 2a)

The $\mathrm{F} \%$ of this typical grass increases on all treatments, even on the control plot. This is probably due to the fact that Lolium perenne is greatly stimulated by balanced grazing. On the ploughed treatment it reaches an F \% of nearly 100 after $6-7$ years, the other species sown having steadily decreased. This again proves the dominating nature of the pasture strain R.v.P. of Lolium.

Poa trivialis (FIG. 2b)

The general trend of the curves of Poa trivialis, a very widely distributed species in permanent grassland on sufficiently humid soils, is the same for all treatments. At the end of 1959 (an exceptionally dry year) a considerable decrease was noted on all treatments, particularly on the reseeded plots and on the "mineral and organic fertilizer" treatment. It took two years for the initial frequency (before the drought) to be restored.

Agrostis species (FIG. 2c)

An increase of frequency due to better grazing technique was found in all treatments. On the reseeded plots the frequency of this species was low, with a slight tendency to increase after some years. 
FIc. 1. The effect of different methods of improving the botanical composition of a permanent pasture, expressed as a percentage of dry weight (period of sampling: July 1963)

\section{Original \\ sward}

1954

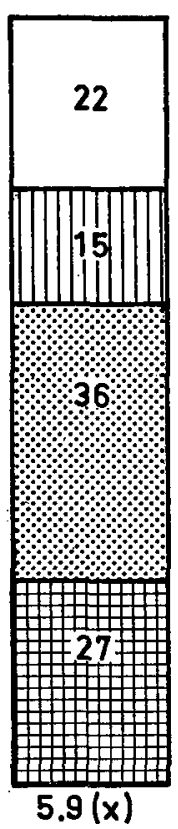

(a)

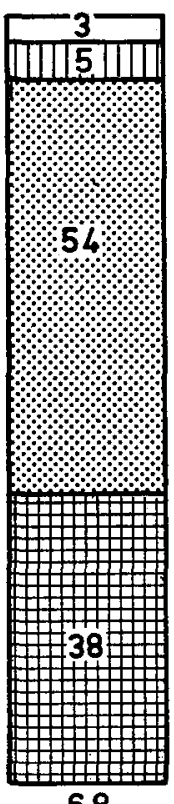

(b)

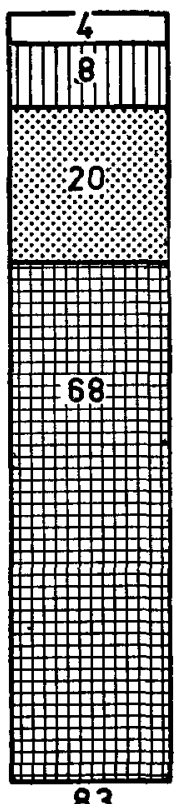

(c)

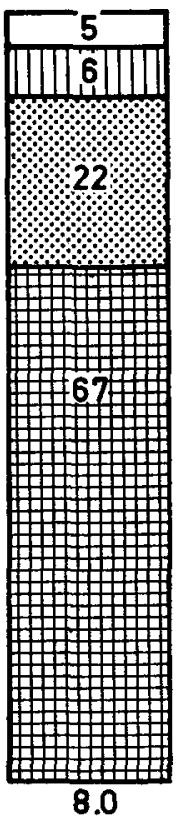

(d)

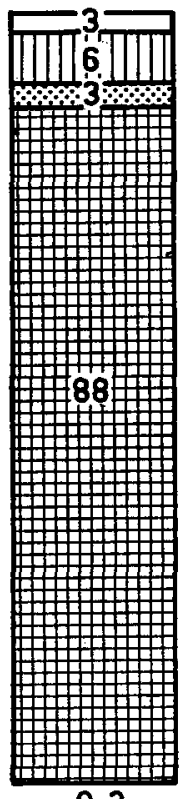

9.2

Quality grade according to DE VRIES, 'T HART and KRUIJNE (1942)

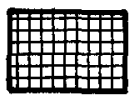

good grasses: Lolium perenne, Festuca pratensis, Poa pratensis, Poa trivialis

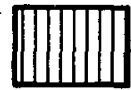

white clover

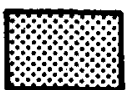

medium-good grasses: Cynosurus cristatus, Agrostis stolonifera, Agropyron repens, Holcus lanatus

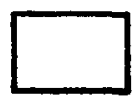

inferior grasses and weeds: Poa annua, Festuca rubra Anthoxanthum odoratum, Bromus mollis, Ranunculus repens, Taraxacum officinale

a. control (rotational grazing only).

b. mineral fertilizers + rotational grazing.

c. mineral and organic fertilizers + rotational grazing.

d. ploughing and reseeding + mineral fertilizers + rotational grazing.

Holcus lanatus (FIG. 2d)

The first years after the trial was laid down, the curve of the control plot first increased and then decreased to reach the 1954 frequency percentage in 1964. On the other hand, rotational grazing, good management (mowing and spreading of droppings) and fertilization lead to a marked depression in the frequency percentage of Holcus lanatus. 
FIG. 2. The effect of different methods of improving the botanical composition of a permanent pasture, expressed in $\mathrm{F} \%$
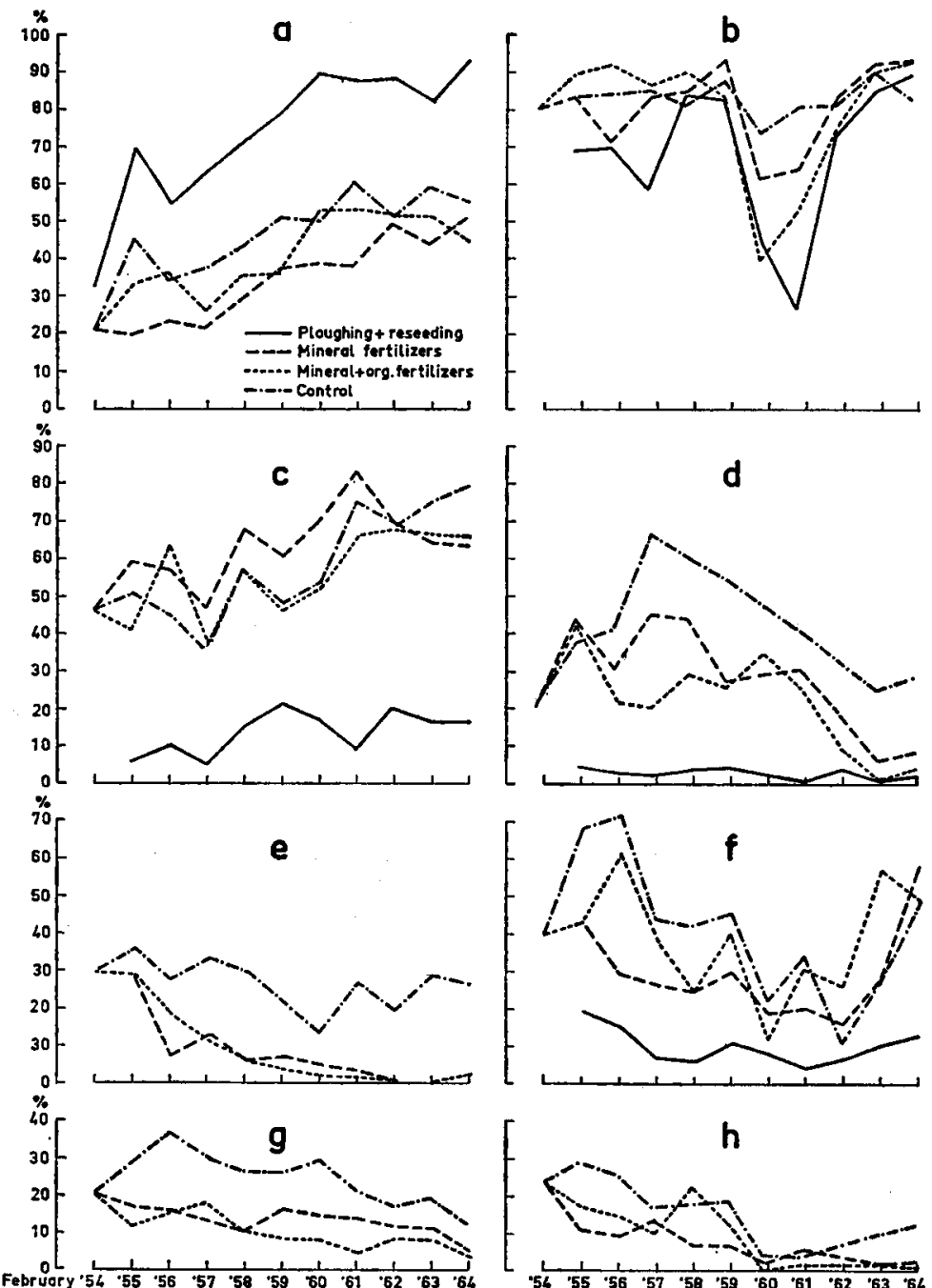

a. Lolium perenne - b. Poa trivialis - c. Agrostic spp. - d. Holcus lanatus - e. Anthoxanthus odoratum - f. Trifolium repens - g. Taraxacum officinale $-\mathrm{h}$. Ranunculus species

Anthoxanthum odoratum (FIG. 2e)

This indicator of poor grassland can not be changed in frequency merely by rotational grazing. On the contrary, it disappears very quickly as a result of fertilization.

Trifolium repens (FIG. 2f)

All treatments have the same general trend: a decrease up to 1960 , followed by an increase. In the case of Trifolium repens it is difficult to say which factors are responsible for these changes. 
Weeds (FIG. 2g and $\mathrm{h}$ )

Taraxacum officinale and Ranunculus species were reduced to a fairly low frequency on all treatments, although it remained the highest on the control plot.

Bromus mollis, a typical hayfield indicator, with an initial frequency percentage of 12 , was completely absent after 3 years of grazing.

Grazing only had very little effect on Agropyron repens. Fertilization, particularly with dung, increased its development from $1 \mathrm{~F} \%$ in 1954 to $4 \mathrm{~F} \%$ in 1964.

\section{Yield data}

The yield data in FIG. 3 indicate that under the prevailing experimental conditions

- ploughing and reseeding with an appropriate seed mixture is a rapid and profitable method. This may be partly due to the use of improved grass and clover strains which show a better response to the fertilizers applied;

Fig. 3. The effect of different methods of improving the dry-matter yields of a permanent pasture

kg d.m./ho

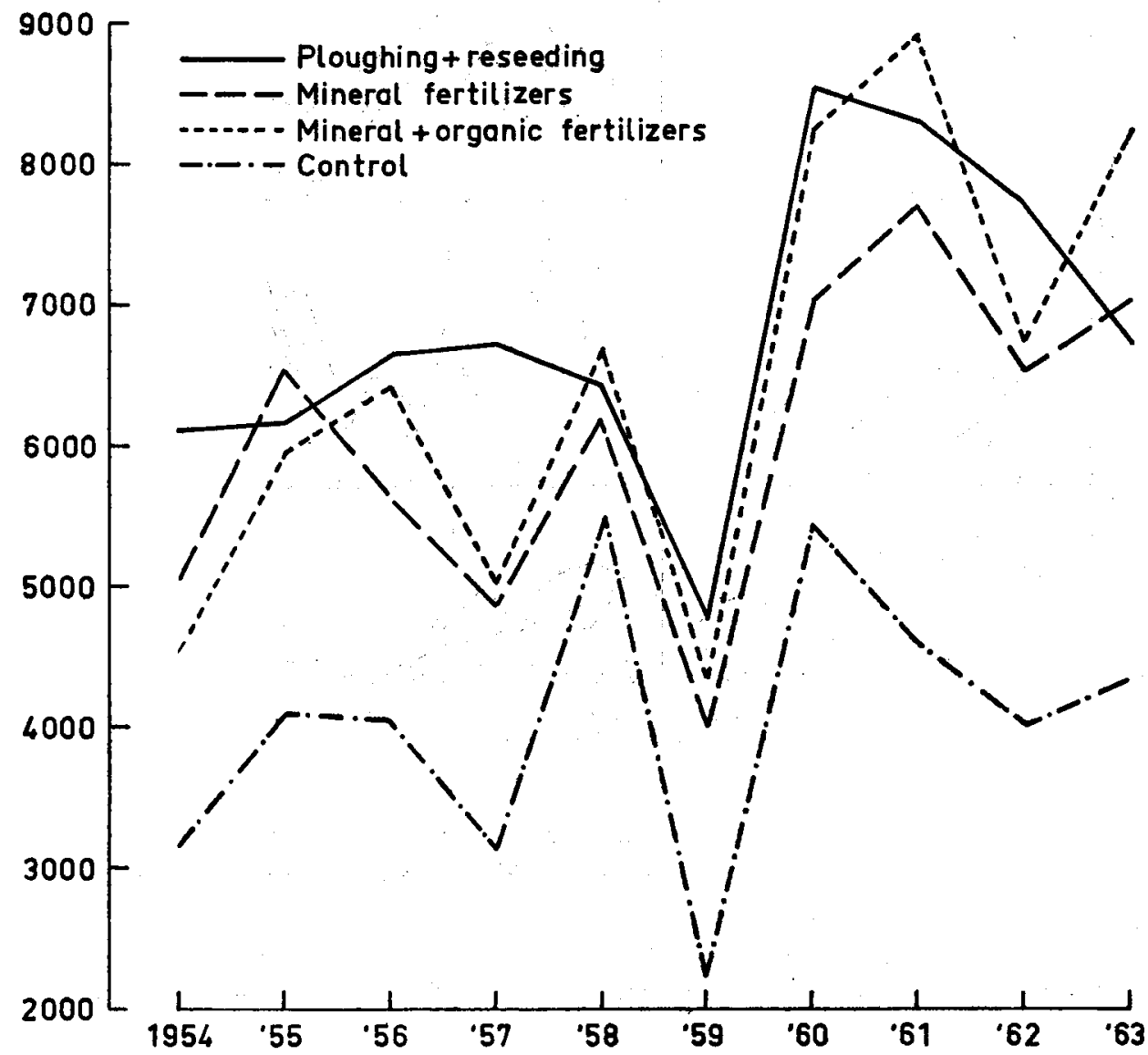


THE EFFECT OF DIFFERENT IMPROVEMENT METHODS ON BOTANICAL COMPOSITION ...

- improvement by mineral fertilizers is a slower process, giving reasonably good results ;

- improvement by mineral and organic fertilizers is slightly more effective;

- the original sward, with rotational grazing as the only improving factor, remains at a low productivity level. No doubt the reason for this low level is the lack of fertilizers, especially nitrogen.

\section{R E F E R E N CES}

VRIES, D. M. DE

M. L. 'T HART en A. A. KruIJne
1937 Methods of determining the botanical composition of hayfields and pastures. Rep. 4th intern. Grassl. Congr. Gt. Brit. $474-480$.

1942 Landbouwkundige waardering van grasland op grond van de plantkundige samenstelling. Ned. kruidk. Arch. 52, 320-324. 